\section{Propagation of Hazelnut Stem Cuttings Using Agrobacterium rhizogenes}

\author{
Nahla V. Bassil', William M. Proebsting, Larry W. Moore ${ }^{2}$, and \\ David A. Lightfoot ${ }^{1}$ \\ Oregon State University, Corvallis, OR 97331
}

Additional index words. Corylus avellana, filbert, rooting

\begin{abstract}
Hazelnut (Corylus avellana L.) softwood cuttings of the cultivars Ennis and Casina were propagated under mist during June and July 1987 and 1988. Rooting of stem cuttings was stimulated by both Agrobacterium and IBA treatment; however, IBA caused nearly complete bud abscission. Better rooting and bud retention were observed in 'Casina' than in 'Ennis' in 1988. Bud retention on Agrobacterium -inoculated cuttings improved as the cuttings approached the semi-hardwood stage. Six months after transplanting, Agrobacterium -inoculated hazelnut cuttings had an extensive root system, characteristic of hairy root. Although the mechanism remains unclear, strains of Agrobacterium rhizogenes are effective rooting agents in hazelnut and may cause less bud abscission than IBA. Chemical name used: $1 \mathrm{H}$-indole-3-butyric acid (IBA).
\end{abstract}

Corylus avellana is propagated primarily because of the difficulties inherent in other methods of propagation that would otherwise be preferred (Lagerstedt, 1970). Propagation of hazelnut by stem cuttings is limited either by poor root initiation (Bergougnoux et al., 1976; Falaschi and Loreti, 1969) or by abscission of the vegetative buds on otherwise One of our approaches to this problem was to study the effects of Agrobactetium rhizogenes on rooting and bud retention.

A. rhizogenes induces formation of adventitious roots at sites of infection, resulting in a hairy-root phenotype. This extensive root formation is caused by expression of $\mathrm{A}$. rhizogenes genes encoded by T-DNA, a fragplasmid (Ri) (Moore et al., 1979). The TDNA is transferred to the host, stably integrated in the plant genome, and expressed (Zambryski, 1988; Zambryski et al., 1989). The genetically transformed plant produces indoleacetic acid and usually opines, as well as adventitious roots (Chilton et al., 1982; Willmitzer et al., 1982).

Shoots of 'Ennis' and 'Casina' hazelnut were collected from lo-year-old trees in July 1987 and June and July 1988. Cuttings consisted of shoot terminals with the apex, one or two expanding leaves, one expanded leaf, and a leafless node at the base. Cuttings were stored overnight at 5C. The following day, cuttings were dipped for $5 \mathrm{sec}$ into a $50 \%$

Received for publication 15 June 1990. Oregon Agricultural Experiment Station Technical Paper no. 9266 . This work was supported, in part, by the Oregon Filbert Commission. We gratefully acknowledge the statistical analysis by Ken Rowe. The cost of publishing this paper was defrayed in part by the payment of page charges. Under postal regulations, this paper therefore must be hereby marked advertisement solely to indicate this fact. 'Dept. of Horticulture. by the use of simple layers. Layerage is used well-rooted cuttings (Lagerstedt, 1970, 1982). ment of DNA originating from a root-inducing

${ }^{2}$ Dept. of Botany and Plant Pathology. ethanol solution of IBA (12.5 mM in 1987 $5 \mathrm{~mm}$ in 1988) or in $50 \% \mathrm{EtOH}$. Treated cuttings were allowed to air dry and then dipped in water or bacterial suspension and placed in a medium consisting of 5 coarse quartz sand : 1 peat $(\mathrm{v} / \mathrm{v})$. Mist frequency was regulated by a light-regulated controller (Solatrol, General Scientific Equipment, Hamden, Conn.) and time switch.

The bacterial strains used in this study were from the collection of L. Moore. A. rhizogenes strains were used singly and in combination $(\mathrm{A} 2+23, \mathrm{~A} 7+22)$ to inoculate hazelnut cuttings and carrot slices. Strain $\mathrm{X}$ 64 resulted from curing strain $\mathrm{A} 4$ of its $\mathrm{Ri}$ plasmid and served as an avirulent control. The inoculum was applied in the form of a bacterial suspension comprising 1.2 to 3.1 $\times 10^{9}$ colony-forming units $/ \mathrm{ml}$.

Each treatment consisted of 30 cuttings, two replicates of 15 cuttings each in randomized complete blocks. Cuttings were evaluated in October for root formation and bud retention. Where analysis of variance indicated significant treatment effects, Student's $t$ test was used to compare means of treatments or groups of particular interest.

Four strains of $A$. rhizogenes were tested in 1987 for their effect on rooting and bud retention on 'Ennis' hazelnut stem cuttings with and without IBA treatment. The bacteria alone generally stimulated more rooting than treatments containing IBA, but this difference was not statistically significant (Tables 1 and 2). All inoculations with virulent bacteria induced greater rooting than water and avirulent bacteria. The difference in rooting percentage between the treatment with bacteria and the water control was significant at $P<0.03$. Treatments with bacteria plus IBA also induced greater rooting than the controls, although $P<0.06$. Bud retention was significantly lower on all IBA-treated cuttings than on cuttings not treated with IBA. As a result, all treatments but one with virulent bacteria alone had a higher percentage of cuttings with both roots and buds than the corresponding bacteria/IBA treatment. Averaged over all treatments, this effect was highly significant. Although $43 \%$ of the watertreated and $60 \%$ of the avirulent-treated cuttings had buds, only $3.3 \%$ of the cuttings in these treatments had both roots and buds. None of the cuttings treated with IBA alone had buds.

'Ennis' and 'Casina' were propagated in Summer 1988. Although rooting percentages were similar in both cultivars, there were marked differences in bud retention. 'Ennis' stem cuttings were propagated on seven dates in 1988, Rooting of bacteria- or IBA-treated cuttings remained $>50 \%$ throughout the sampling period, whereas rooting of the untreated cuttings declined significantly by 6 July $(P<0.001)$ (Table 3$)$. Over this entire period, cuttings inoculated with bacteria alone rooted significantly better than with bacteria plus IBA $(P<0.001)$. In contrast, bud retention on 'Ennis' cuttings in all treatments was $<15 \%$ on all dates sampled. There was a small increase in bud retention on the waterand bacteria-treated cuttings on the last date, which was the same date as the 1987 experiment. This increase was statistically significant, because bud retention on all IBA-treated
Table 1. Effect of Agrobacterium rhizogenes and IBA on rooting percentage, percentage of cuttings with one or more buds, and percentage of rooted cuttings with one or more buds of hazelnut 'Ennis' stem cuttings propagated on 26 July 1987.

\begin{tabular}{lccc}
\hline Treatment & $\begin{array}{c}\text { Roots } \\
(\%)\end{array}$ & $\begin{array}{c}\text { Buds } \\
(\%)\end{array}$ & $\begin{array}{c}\text { Roots + buds } \\
(\%)\end{array}$ \\
\hline Water & 16.7 & 43.3 & 3.3 \\
IBA, $12.5 \mathrm{mM}$ & 10.0 & 0 & 0 \\
X-64 & 6.7 & 60.0 & 3.3 \\
X-64 + IBA & 20.0 & 0 & 0 \\
A2 & 36.7 & 50.0 & 23.3 \\
A2 + IBA & 26.7 & 13.3 & 6.7 \\
23 & 46.7 & 63.3 & 43.3 \\
$23+$ IBA & 40.0 & 6.7 & 3.3 \\
A2 +23 & 46.7 & 36.7 & 16.7 \\
A2 $+23+$ IBA & 40.0 & 23.3 & 20.0 \\
A7 & 30.0 & 63.3 & 16.7 \\
A7 + IBA & 26.7 & 13.3 & 6.7 \\
22 & 30.0 & 53.3 & 13.3 \\
$22+$ IBA & 46.7 & 16.7 & 10.0 \\
A7 +22 & 56.7 & 53.3 & 30.0 \\
A7 $+22+$ IBA & 46.7 & 10.0 & 6.7 \\
\hline
\end{tabular}


Table 2. Significance of comparisons, determined by $t$ test, between treatment effects on rooting percentage (Roots), percentage of cuttings with one or more buds (Buds), and percentage of rooted cuttings with one or more buds (Roots + buds) of hazelnut 'Ennis' propagated in 1987.

\begin{tabular}{lccc}
\hline & \multicolumn{3}{c}{ Treatment } \\
\cline { 2 - 4 } Treatment & Water & IBA & Bacteria \\
\hline IBA & $\begin{array}{c}\text { Roots } \\
\text { NS }\end{array}$ & & \\
Bacteria & $*$ & $* *$ & \\
Bacteria + IBA & NS & $*$ & NS \\
& $\begin{array}{l}\text { Buds } \\
\text { IBA }\end{array}$ & & \\
Bacteria & NS & $* * *$ & \\
Bacteria + IBA & $* *$ & NS & $* * *$ \\
& Roots + buds & \\
IBA & NS & $* *$ & \\
Bacteria & $* *$ & $* *$ & \\
Bacteria + IBA & NS & NS & $* * *$ \\
\hline
\end{tabular}

Ns, $*, * *, * * *$ Nonsignificant and significant difference at $P=0.05,0.01$, and 0.001 , respectively.

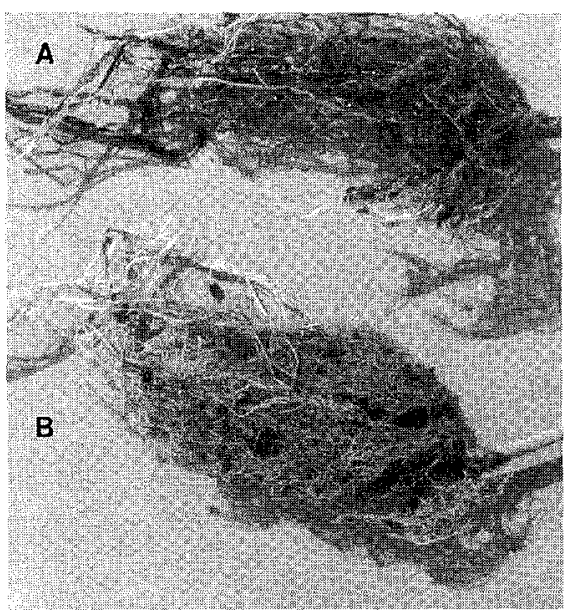

Fig. 1. Phenotype of roots treated with IBA (A) or Agrobacterium rhizogenes (B). Note difference in density of root systems.

cuttings was zero. Since bud retention was low, the number of cuttings with both buds and roots was also low ( $\geq 10 \%)$, with similar statistical significance. On 'Casina', bacteria-, IBA-, and bacteria/IBA-treated cuttings rooted significantly better than water-treated cuttings (Table 4), with $P<0.001$ in each case. Bud retention on cuttings treated with IBA was significantly lower than the water$(P<0.001)$ or bacteria-treated $(P<0.001)$ cuttings without IBA averaged over all sampling dates. As a consequence, the percentage of cuttings with both roots and buds was significantly greater over all sampling dates in the water- $(P<0.01)$ and bacteria-treated $(P<0.001)$ cuttings than in treatments with IBA. By the last sampling date (6 July), the two treatments with bacteria only resulted in a mean of $65 \%$ of the cuttings having both roots and buds, significantly greater $(P<$ $0.001)$ than the water inoculation on that date Averaged over the three sampling dates, the percentage of cuttings with both roots and buds in the water and bacterial treatments was not significantly different.

Table 3. Effect of Agrobacterium rhizogenes and IBA on rooting percentage, percentage of cuttings with one or more buds, and percentage of rooted cuttings with one or more buds of hazelnut 'Ennis' stem cuttings propagated in 1988.

\begin{tabular}{lccc}
\hline Treatment & $\begin{array}{c}\text { Roots } \\
(\%)\end{array}$ & $\begin{array}{c}\text { Buds } \\
(\%)\end{array}$ & $\begin{array}{c}\text { Roots + buds } \\
(\%)\end{array}$ \\
\hline Water & 96.7 & 3 June & 10.0 \\
IBA, $5 \mathrm{mM}$ & 90.0 & 10.0 & 0 \\
$\mathrm{~A} 2+23$ & 66.7 & 0 & 0 \\
$\mathrm{~A} 2+23+$ IBA & 53.3 & 3.3 & 0 \\
$\mathrm{~A} 7+22$ & 100.0 & 0 & 3.3 \\
$\mathrm{~A} 7+22+$ IBA & 56.7 & 0 & 0
\end{tabular}

Water
IBA, $5 \mathrm{mM}$
$\mathrm{A} 2+23$
$\mathrm{~A} 2+23+\mathrm{IBA}$
$\mathrm{A} 7+22$
$\mathrm{~A} 7+22+\mathrm{IBA}$

14 June

56.7

96.7

96.7

76.7

90.0

63.3

Water

IBA, $5 \mathrm{mM}$

$\mathrm{A} 2+23$

$\mathrm{A} 2+23+\mathrm{IBA}$

A7 +22

A7 $+22+$ IBA

3.3

0

0

0

0

$\mathrm{X}-64$

X-64 + IBA

Water

IBA, $5 \mathrm{~mm}$

$\mathrm{A} 2+23$

$\mathrm{A} 2+23+\mathrm{IBA}$

73.3

76.7

76.7

80.0

96.7

93.3

56.7

66.7

A7 +22

A7 $+22+$ IBA

26.7

86.7

86.7

86.7

86.7

76.7

Water

IBA, $5 \mathrm{~mm}$

46.7

$\mathrm{A} 2+23$

83.3

83.3
53.3

$\mathrm{A} 2+23+\mathrm{IBA}$

$\mathrm{A} 7+22$

76.6

A7 $+22+$ IBA

50.0

$\mathrm{X}-64$

10.0

$\mathrm{X}-64+\mathrm{IBA}$

66.7

Water

16.7

IBA, $5 \mathrm{mM}$

53.3

$\mathrm{A} 2+23$

$\mathrm{A} 2+23+\mathrm{IBA}$

86.7

A7 +22

$\mathrm{A} 7+22+\mathrm{IBA}$

56.7

$\mathrm{X}-64$

76.7

70.0

$X-64+$ IBA

36.7

56.7

\section{July}

$\begin{array}{ll}0 & 0 \\ 0 & 0 \\ 3.3 & 3.3 \\ 0 & 0 \\ 0 & 0 \\ 0 & 0 \\ 0 & 0 \\ 0 & 0\end{array}$

$6 \mathrm{July}$

$\begin{array}{ll}3.3 & 3.3 \\ 0 & 0 \\ 0 & 0 \\ 0 & 0 \\ 0 & 0 \\ 0 & 0\end{array}$

Once graded, the rooted cuttings were transplanted and grown. The following spring, the root systems of the cuttings inoculated with bacteria were uniformly much more dense than those of the controls, a characteristic of hairy root (Fig. 1). The roots on the IBA- and water-treated cuttings appeared normal and lacked the extensive development of secondary roots found on plants originally inoculated with bacteria. Samples of homogenized roots were streaked on mannitol-glutamate-yeast extract and biovar-2 plates to test for the presence of Agrobacterium. After two days of incubation at $25 \mathrm{C}$, Agrobacterium colonies appeared on both plates streaked from samples of Agrobacterium -inoculated tissue, but not from untreated tissue. Therefore, there was no or very little cross-contamination in the beds.
As reported by Lagerstedt (1982), bud abscission is a serious obstacle to propagation of hazelnut stem cuttings, even though the rooting percentage may be acceptable. Our results demonstrated that A. rhizogenes inoculation can mitigate this problem, stimulating root initiation to a degree comparable to IBA without increasing bud abscission. The bacteria did not, however, ameliorate bud abscission induced by IBA treatment. The avirulent strain of Agrobacterium failed to induce rooting, evidence that T-DNA is required for this response. The effects on cutting development were influenced by both cultivar and date. 'Ennis' was more prone to bud abscission than 'Casina' and varied markedly in the 2 years tested. Bud retention in both cultivars improved as the shoot matured. 
Table 4. Effect of Agrobacterium rhizogenes and IBA on rooting percentage, percentage of cuttings with one or more buds, and percentage of rooted cuttings with one or more buds of hazelnut 'Casina' stem cuttings propagated in 1988.

\begin{tabular}{|c|c|c|c|c|}
\hline $\begin{array}{l}\text { Date of } \\
\text { sampling }\end{array}$ & Treatment & $\begin{array}{c}\text { Roots } \\
(\%)\end{array}$ & $\begin{array}{c}\text { Buds } \\
(\%)\end{array}$ & $\begin{array}{c}\text { Roots }+ \text { buds } \\
(\%)\end{array}$ \\
\hline \multirow[t]{6}{*}{14 June } & Water & 26.7 & 20.0 & 20.0 \\
\hline & IBA, $5 \mathrm{mM}$ & 80.0 & 0 & 0 \\
\hline & $\mathrm{A} 2+23$ & 90.0 & 13.3 & 13.3 \\
\hline & $\mathrm{A} 2+23+\mathrm{IBA}$ & 60.0 & 0 & 0 \\
\hline & $A 7+22$ & 100.0 & 43.3 & 43.3 \\
\hline & $A 7+22+$ IBA & 73.3 & 3.3 & 3.3 \\
\hline \multirow[t]{8}{*}{23 June } & Water & 50.0 & 20.0 & 20.0 \\
\hline & IBA, $5 \mathrm{mM}$ & 93.3 & 23.3 & 23.3 \\
\hline & $A 2+23$ & 73.3 & 16.7 & 16.7 \\
\hline & $\mathrm{A} 2+23+\mathrm{IBA}$ & 86.7 & 0 & 0 \\
\hline & $A 7+22$ & 80.0 & 0 & 0 \\
\hline & $\mathrm{A} 7+22+\mathrm{IBA}$ & 80.0 & 0 & 0 \\
\hline & $X-64$ & 60.0 & 16.7 & 16.7 \\
\hline & $X-64+I B A$ & 90.0 & 0 & 0 \\
\hline \multirow[t]{6}{*}{6 July } & Water & 20.0 & 20.0 & 20.0 \\
\hline & $\mathrm{IBA}, 5 \mathrm{mM}$ & 80.0 & 0 & 0 \\
\hline & $\mathrm{A} 2+23$ & 90.0 & 70.0 & 70.0 \\
\hline & $\mathrm{A} 2+23+\mathrm{IBA}$ & 70.0 & 5.0 & 5.0 \\
\hline & $A 7+22$ & 95.0 & 60.0 & 60.0 \\
\hline & $\mathrm{A} 7+22+\mathrm{IBA}$ & 75.0 & 0 & 0 \\
\hline
\end{tabular}

There are several possible reasons for the lower bud retention on 'Ennis' cuttings propagated in 1988 than in 1987. Differences in development may account for the different rooting each year. Determining whether bud retention improves as the shoot matures, without concomitant loss of rooting potential, would help assess the practicality of A. rhizogenes inoculations in propagating hazelnut. Another difference between 1987 and 1988 was the change in IBA concentration from $12.5 \mathrm{~mm}$ to $5 \mathrm{~mm}$, the latter recommended by Lagerstedt (1982). Lowering the by reduced bud abscission, the factor limiting propagation of hazelnut.

\section{Literature Cited}

Bergougnonx, F., A. Verlhac, and O. Verlhac. 1976. Bouturage du noisetier sous brumisation. Compte Rendu d' Essai no. 369. 1 Dec. Inst. Nat. Vulgar. Fruits, Legumes et Champignons. Ctr. Expt. Chataigner, Noyer et Noisetier. Malemort, France.

Chilton, M.D., D.A. Tepfer, A. Petit, F. CasseDelbart, and J. Tempe. 1982. Agrobacterium rhizogenes inserts T-DNA into the genomes of the host plant root cells. Nature (London) 295:432-434.

Falaschi, R., and F. Loreti. 1969. Observazioni sulla propagazione del nocciola per talea di ramo con la tecnica del "riscaldamento basale". Estatto dalla "Rivista dell Ortoflorofrutticulture Italiana”. vol. 53, no. 6 .

Lagerstedt, H.B. 1970. Filbert propagation techniques. Ann. Rpt. Northern Nut Growers Assn. 61:61-67.

Lagerstedt, H.B. 1982. Three promising hazelnut propagation techniques. Proc. Nut Growers Soc. 67:58-66.

Moore, L.W., G. Warren, and G. Strobel. 1979. Involvement of a plasmid in the hairy root disease of plants caused by Agrobacterium rhizogenes. Plasmid 2:617-626.

BA concentration, however, likely did not account for the observed effects on bud abscission.

Whether A. rhizogenes transformed filbert tissue is unclear. Our initial molecular analyses for $T_{R}$ - and $T_{L}$-DNA and the presence of opines were equivocal. Regardless of the mechanism of root initiation, our results demonstrate that strains of $A$. rhizogenes can improve propagation of hazelnut stem cuttings. In itself, the bacterium is an effective rooting agent. Furthermore, the effect of A. rhizogenes can be distinguished from IBA
Willmitzer, L., J. Sanchez-Serrano, E. Buschfeld, and J. Schell. 1982. DNA from Agrobacterium rhizogenes is transferred and expressed in axenic hairy root plant tissues. Mol. Gen. Genet. $186: 16-22$.

Zambryski, P. 1988. Basic processes underlying Agrobacterium -mediated DNA transfer to plant cells. Annu. Rev. Genet. 22:1-30.

Zambryski, P., J. Tempe, and J. Schell. 1989. Transfer and function of T-DNA genes from Agrobacterium $\mathrm{Ti}$ and $\mathrm{Ri}$ plasmids in plants. Cell 56:193-201. 